\title{
Pengaruh Model Contextual Teaching And Learning (CTL) Dengan Scaffolding Terhadap Kemampuan Koneksi Matematis Di SMP Negeri 6 Kota Bengkulu
}

\author{
Azes Yudha \\ Program Studi Pascasarjana Pendidikan Matematika FKIP Universitas Bengkulu \\ yudhaazes499@gmail.com
}

\begin{abstract}
Abstrak
Penelitian ini bertujuan untuk mengetahui Pengaruh Model Contextual Teaching And Learning (CTL) Dengan Scaffolding Terhadap Kemampuan Konekai Matematis di SMP Negeri 6 Kota Bengkulu. Jenis penelitian ini adalah penelitian eksperimen semu (quasy experiment) yaitu nonequivalent control group design. Populasi dalam penelitian ini adalah siswa kelas VII SMP Negeri 6 Kota Bengkulu. Sampel dalam penelitian ini diperlukan 2 kelas yang mempunyai distribusi normal dan varians yang homogen adalah siswa kelas VII C dan VII E SMP Negeri 6 Kota Bengkulu. Hasil penelitian ini adalah terdapat Pengaruh Model Contextual Teaching And Learning (CTL) Dengan Scaffolding Terhadap Kemampuan Koneksi Matematis di SMP Negeri 6 Kota Bengkulu, dengan besar pengaruh model pembelajaran Contextual Teaching and Learning (CTL) dengan Scaffolding terhadap kemampuan koneksi matematis siswa sebesar $35.1 \%$.
\end{abstract}

Kata Kunci : Model Contextual Teaching And Learning (CTL), Scaffolding, Kemampuan Koneksi Matematis

\section{Pendahuluan}

Menurut Hendriana (2014) menyatakan kemampuan koneksi matematika adalah komponen kognitif dari pembelajaran matematika yang harus dikembangkan oleh siswa sekolah menengah. Menurut Saminanto (2015) menyatakan bahwa kemampuan koneksi matematis adalah kemampuan dalam menghubungkan antar konsep dalam matematika dan menghubungkan konsep matematika dengan konsep bukan matematika. Menurut Muin (2014) bahwa kemampuan koneksi matematis adalah kemampuan untuk menemukan hubungan berbagai representasi konsep matematis dan menerapkannya dalam kehidupan sehari-hari. Menurut Rohendi (2013) koneksi matematika merupakan kapasitas di atas informasi yang diberikan, dengan sikap kritis untuk mengevaluasi sesuatu dan memiliki kesadaran metakognitif dan kemampuan pemecahan masalah. Saleh. H. (2017) menyatakan bahwa kemampuan koneksi matematika merupakan kemampuan mendasar yang harus dimiliki siswa.

Berdasarkan pendapat para ahli di atas dapat disimpulkan bahwa kemampuan koneksi matematis adalah salah satu komponen kognitif siswa dalam pembelajaran matematika yang digunakan untuk menemukan hubungan konsep-konsep matematika dan konsep bukan matematika serta menerapkannya dalam kehidupan sehari-hari.

Berdasarkan observasi lapangan dan wawancara yang dilakukan peneliti dengan salah satu guru matematika di SMP Negeri 6 Kota Bengkulu pada tanggal 4 Oktober 2017, bahwa dalam proses pembelajaran di kelas masih menggunakan pembelajaran yang berpusat pada guru. Dengan pembelajaran seperti ini, partisipasi dan keaktifan siswa dalam proses belajar belum optimal. Masih banyak siswa yang belum bisa mengkaitkan konsep-konsep matematika untuk menyelesaikan masalah yang diberikan oleh guru. Selain itu, masih banyak siswa 
mengalami kesulitan dalam menyelesaikan soal yang berkaitan dengan kehidupan sehari-hari. Siswa juga masih kesulitan dalam menentukan rumus apa yang akan dipakai jika dihadapkan pada soal yang berkaitan dengan masalah kehidupan sehari-hari.

Berhubungan dengan kemampuan koneksi matematika siswa, peneliti melakukan studi pendahuluan dengan memberikan siswa soal-soal yang telah dipelajari yang berkaitan dengan kemampuan koneksi matematika, ternyata siswa masih belum dapat menyelesaikannya dengan baik. Terlihat dari hasil yang diperoleh dari 33 siswa hanya ada 2 siswa yang mampu menjawab soal sebanyak 53,3\%. Rata-rata siswa hanya mampu menghubungkan informasi dalam soal dengan materi sebelumnya, materi yang berkaitan dengan disiplin ilmu lain atau mata pelajaran lain, dan materi yang menghubungkan masalah kehidupan nyata pada soal kedalam materi yang telah dipelajari dengan benar tetapi jawaban atau penyelesaiannya masih salah. Dan belum ada siswa yang mampu mencapai skor maksimal. Hasil ini menunjukan bahwa kemampuan koneksi matematika siswa di SMP Negeri 6 Kota Bengkulu masih rendah.

Rendahnya kemampuan koneksi matematis siswa itu disebabkan karena pembelajaran matematika di kelas kurang mengembangkan kemampuan koneksi matematis siswa. Selain itu, model dan teknik pembelajaran yang diterapkan oleh guru dalam proses pembelajaran juga masih kurang mengembangkan koneksi matematis siswa.

Berdasarkan uraian di atas, maka diperlukan adanya peningkatan kualitas dan inovasi dalam pembelajaran matematika. Fakta tersebut sesuai dengan yang dikemukakan oleh Widada (2015) bahwa peningkatan kualitas pembelajaran dapat dicapai melalui pembelajaran yang berkualitas. Salah satu model pembelajaran yang dapat meningkatkan kualitas pembelajaran dan dapat mengembangkan koneksi matematis siswa dalam menyelesaikan permasalahan pada saat proses kegiatan belajar mengajar di kelas yaitu Contextual Teaching and Learning (CTL). Fadillah, dkk (2017) mengatakan bahwa: Contextual Teaching and Learning (CTL) is a conception of teaching and learning that helps teachers relate subject matter content to real world situations, and motivates students to make connections between knowledge and its application to heir daily lives. nArtinya model pembelajaran Contextual Teaching and Learning (CTL) merupakan konsepsi pengajaran dan pembelajaran yang membantu guru menghubungkan konten materi pelajaran dengan situasi dunia nyata, dan memotivasi siswa untuk membuat hubungan antara pengetahuan dan penerapannya terhadap kehidupan mereka sehari-hari. Contextual Teaching and Learning (CTL) adalah konsep belajar yang membantu guru mengaitkan materi yang diajarkannnya dengan situasi dunia nyata peserta didik dan mendorong peserta didik membuat hubungan antara pengetahuan yang dimilikinya dengan penerapannya dalam kehidupan mereka sehari-hari, dengan melibatkan tujuh komponen yaitu: 1) konstruktivisme, 2) bertanya, 3) menemukan, 4) masyarakat belajar, 5) pemodelan, 6) refleksi, dan 7) penilaian sebenarnya. Dengan menerapkan model pembelajaran Contextual Teaching and Learning (CTL) kemampuan koneksi matematis siswa akan lebih mudah dikembangkan karena dengan model pembelajaran ini siswa langsung dibawa dengan suatu persoalan dengan mengaitkannya dengan dunia nyata.

Model Contextual Teaching and Learning (CTL) perlu didukung dengan teknik pembelajaran yang tepat supaya pembelajaran di kelas lebih efisien. Guru hendaknya melibatkan siswa sehingga siswa bisa menyelesaikan masalah secara mandiri. Salah satu teknik pembelajaran yang cocok untuk mendukung model pembelajaran adalah teknik scaffolding. Scaffolding menurut Amiripour, Mofidi, dan Shahvarani (2012):

Scaffolding is a mechanism for observing the process by which a learner is helped to achieve his or her potential learning. Regard to nature of scaffolding, it seems that scaffolding process can have an effect on learning and teaching procedure. 
Artinya Scaffolding merupakan mekanisme untuk mengamati proses belajar siswa, yang dibantu untuk mencapai pembelajaran maksimal mereka, dalam hal ini dikenal dengan perkembangan potensial. Berkaitan dengan sifat alamiah Scaffolding, terlihat bahwa proses Scaffolding memiliki pengaruh terhadap kegiatan belajar mengajar. Oleh karena itu, teknik Scaffolding dapat memberikan pengaruh terhadap pembelajaran Contextual Teaching and Learning (CTL). Dengan demikian Contextual Teaching and Learning (CTL) dengan teknik Scaffolding dapat mencapai pembelajaran secara maksimal lihat juga (W. Widada, Herawaty, \& Lubis, 2018)(Herawaty \& Rusdi, 2016)(Wahyu Widada, 2004)(Wahyu Widada et al., 2019).

\section{Metode Penelitian}

Jenis penelitian yang digunakan adalah penelitian eksperimen semu (quasy experiment) yaitu nonequivalent control group design. Jenis penelitian ini adalah penelitian eksperimen semu (quasy experiment) yaitu nonequivalent control group design. Populasi dalam penelitian ini adalah siswa kelas VII SMP Negeri 6 Kota Bengkulu. Sampel dalam penelitian ini diperlukan 2 kelas yang mempunyai distribusi normal dan varians yang homogen. adalah siswa kelas VII C dan VII E SMP Negeri 6 Kota Bengkulu.

Data yang digunakan dalam penelitian ini adalah data tes kemampuan koneksi matematis. Tes diberikan pada kelas eksperimen model pembelajaran CTL dengan scaffolding dan kelas kontrol model pembelajaran konvensional dalam bentuk uraian dengan soal yang sama. Tes bertujuan untuk melihat hasil kemampuan koneksi matematis kelas model CTL dan kelas model pembelajaran konvensional.

\section{Hasil Dan Pembahasan}

Untuk mengetahui hasil uji hipotesis terlebih dahulu dilakukan uji normalitas dan uji homogenitas terhadap hasil pretes dan postes dengan menggunakan SPSS 16. Hasil uji normalitas diperoleh bahwa kedua kelas berdistribusi normal dan hasil uji homogenitas diperoleh kedua kelas menunnjukkan varian yang sama.

Berdasarkan pengujian terhadap pretes dan postes kelas eksperimen dan kontrol dengan uji Anacova menunjukkan bahwa hasil belajar siswa pada kedua kelas tidak berbeda secara signifikan. Dengan demikian dapat dikatakan bahwa kemampuan awal kedua kelas adalah sama.

Sedangkan hasil pengolahan posttes, didapatkan bahwa perbedaan hasil belajar yang signifikan setelah penerapan model pembelajaran Contextual Teaching and Learning (CTL) dengan Scaffolding pada kelas eksperimen dan pembelajaran konvensional pada kelas kontrol. Nilai rerata pada kelas eksperimen adalah 81.34 sedangkan kelas kontrol adalah 71.69 (Tabel $1)$.

Tabel 1 Data Koneksi Matematis Pada Kelas Penelitian

\begin{tabular}{|l|c|c|c|c|}
\hline \multirow{2}{*}{ Kelas Penelitian } & \multicolumn{4}{c|}{ Deskriptif data } \\
\cline { 2 - 5 } & Min & Maks & Mean & Std. Deviation \\
\hline Eksperimen & 69 & 95 & 81.34 & 7.19 \\
\hline Kontrol (Konvensional) & 59 & 87 & 71.69 & 7.48 \\
\hline
\end{tabular}

Pada pengujian hipotesis pertama terdapat pengaruh antara model pembelajaran Contextual Teaching and Learning (CTL) dengan Scaffolding dalam mempengaruhi kemampuan koneksi matematika. Artinya siswa yang diajar dengan menggunakan model pembelajaran Contextual 
Teaching and Learning (CTL) dengan Scaffolding saling mempengaruhi terhadap kemampuan koneksi matematika. Lihat Tabel 2

Tabel 2 Uji Anacova

\begin{tabular}{|l|c|c|c|c|c|c|}
\hline Source & $\begin{array}{c}\text { Type III Sum of } \\
\text { Squares }\end{array}$ & Df & $\begin{array}{c}\text { Mean } \\
\text { Square }\end{array}$ & F & Sig. & $\begin{array}{c}\text { Partial Eta } \\
\text { Squared }\end{array}$ \\
\hline Corrected Model & $1694.314^{\mathrm{a}}$ & 2 & 847.157 & 16.501 & .000 & .351 \\
Intercept & 17091.007 & 1 & 17091.007 & 332.906 & .000 & .845 \\
Pretes_Koneksi & 202.423 & 1 & 202.423 & 3.943 & .052 & .061 \\
Kelas & 1693.846 & 1 & 1693.846 & 32.993 & .000 & .351 \\
Error & 3131.671 & 61 & 51.339 & & & \\
Total & 379523.000 & 64 & & & & \\
Corrected Total & 4825.984 & 63 & & & & \\
\hline
\end{tabular}

a. $\mathrm{R}$ Squared $=.351$ (Adjusted R Squared $=.330)$

Dari Tabel 2 Pada baris (model_pembelajaran) nilai F hitung sebesar 32.993 dan nilai sig $(0,000)<\alpha(0,05)$. Dengan demikian Ho ditolak dan H1 diterima. Jadi terdapat terdapat pengaruh antara variabel pendekatan pembelajaran dengan variable nilai pos-test. Artinya terdapat pengaruh model pembelajaran Contextual Teaching and Learning (CTL) dengan Scaffolding terhadap Koneksi Matematis Siswa sebesar $35.1 \%$.

\section{Simpulan Dan Saran}

Kesimpulan dari penelitian ini adalah terdapat pengaruh model pembelajaran Contextual Teaching and Learning (CTL) dengan Scaffolding terhadap kemampuan koneksi matematis siswa. Besar pengaruh model pembelajaran Contextual Teaching and Learning (CTL) dengan Scaffolding terhadap kemampuan koneksi matematis siswa sebesar $35,1 \%$.

Guru matematika di Bengkulu hendaknya dapat menggunakan model pembelajaran yang lebih inovatif dan lebih bervariasi seperti mengimplementasikan Model pembelajaran Contextual Teaching and Learning (CTL) dengan Scaffolding dapat mendekatkan interaksi siswa di kelas. Baik itu interaksi antara siswa dan siswa, siswa dan guru, juga interaksi antara siswa dengan materi. Karena koneksi matematis dapat dicapai siswa sebagai hasil dari proses interaksi.

\section{DAFTAR PUSTAKA}

Fadillah, A. N. P. (2017). The Effect of Application of Contextual Teaching and Learning (CTL) Model-Based on Lesson Study With Mind Mapping Media to Assess Student Learning Outcomes on Chemistry on Colloid Systems. International Journal of Science and Applied Science , 101-108.

Herawaty, D., \& Rusdi, R. (2016). Increased Capacity Of The Understanding Of The Concept And The Ability To Solve Problems Through The Implementation Of The 
Model Of Teaching Mathematics Realistic Based On Cognitive Conflict Students. Journal of Mathematics Education (Infinity), 5(2), 109-120. https://doi.org/10.22460/infinity.v5i2.217

Hendriana, S.S (2014) Mathematical Connection Ability And Self-Confidence (An Experiment On Junior High School Students Throughcontextual Teaching And Learning With Mathematical Manipulative). International Journal of Education, Vol. 8 No. 1 December 2014

Muin, A. C. (2014). The Achievement of Mathematical Connection Skills Based on Cognitive Level Through Means Ends Analysis (Mea) Strategy of Learning. Proceeding of International Conference on Research Implementation and Education of Mathematics and Sciences , 21-32.

Rohendi, D. (2013). Connected Mathematics Project (CMP) Model Based on Presentation Media to the Mathematical Connection Ability of Junior High School Student. Journal of Education and Practice , 17-22.

Wahyu Widada. (2015) Proses Pencapaian Konsep Matematika dengan Memanfaatkan Media Pembelajaran Kontekstual : Salah Satu Dari Bagian Penelitian Pengembangan Struktur Representasi Pengetahuan Berbasis Extended TRIAD ${ }^{++}$. Prosiding Seminar Nasional dan Lomba Media Pembelajaran. STKIP PGRI Lubuk Linggau, 21-22 November 2015

Widada, W., Herawaty, D., \& Lubis, A. N. M. T. (2018). Realistic mathematics learning based on the ethnomathematics in Bengkulu to improve students' cognitive level. Journal of Physics: Conference Series, 1088. https://doi.org/10.1088/17426596/1088/1/012028

Widada, Wahyu. (2004). Pendekatan Pembelajaran Matematika Berbasis Masalah. Surabays: Unipa Press.

Widada, Wahyu, Herawaty, D., Falaq, A., Anggoro, D., Yudha, A., \& Hayati, M. K. (2019). Ethnomathematics and Outdoor Learning to Improve Problem Solving Ability. Advances in Social Science, Education and Humanities Research, Volume 295, 295(ICETeP 2018), 13-16. 